Proceedings of the 10th International Ruminant Reproduction Symposium (IRRS 2018); Foz do Iguaçu, PR, Brazil, September 16th to 20th, 2018.

\title{
The variable success of in vitro maturation: can we do better?
}

\author{
Alberto M. Luciano*, Federica Franciosi, Rodrigo G. Barros, Cecilia Dieci, Valentina Lodde \\ Reproductive and Developmental Biology Laboratory, Department of Health, Animal Science and Food Safety, \\ University of Milan, 20133 Milan, Italy.
}

Abstract

The efficiency of in vitro assisted reproductive technologies, consisting of the transfer of embryos obtained in vitro through in vitro maturation, in vitro fertilization and early embryo culture is still limited. The quality of the oocytes is pivotal for assisted reproductive efficiency and the maturation of the oocyte represents the first key limiting step of the in vitro embryo production system. At the time of removal from the antral follicles, the oocyte is still completing the final growth and differentiation steps, needed to provide the so-called developmental competence, i.e. the machinery required to sustain fertilization and embryo development. In mono-ovular species only one oocyte per cycle is available for procreation, therefore the current assisted reproduction techniques strive to overcome this natural boundary. However, the success is still limited and overall the effectiveness does not exceed the efficiency achieved in millions of years of mammalian evolution. One of the problems lies in the intrinsic heterogeneity of the oocytes that are subjected to in vitro maturation and in the lack of dedicated in vitro approaches to finalize the differentiation process. In this review we will try to overview some of the salient aspects of current practices by emphasizing the most critical and fundamental features in oocyte differentiation that should be carefully considered for improving current techniques.

Keywords: cAMP, cGMP, chromatin, gap junction, meiotic arrest, oocyte, pre-IVM.

\section{Introduction: the math of the in vitro embryo production (IVP) system}

In cattle the efficiency of in vitro assisted reproductive technologies (ART), entailing of the transfer of embryos obtained through in vitro maturation (IVM), in vitro fertilization (IVF) and in vitro early embryo culture (IVC) is still limited.

Despite the potential advances offered by in vitro embryo production (IVP) systems, the percentage of success in cow remained stunning stable over the last 30 years and is limited to one third of the oocytes isolated from the ovary reaching the blastocyst stage of embryonic development (Lonergan and Fair, 2008; Galli, 2017). In bovine IVP, on a percentage basis, starting from 100 oocytes only about one third become a blastocyst after IVM, IVF and IVC, and only about one third of these embryos are able to produce a born calf (Fig. 1). Considering that, on average, 5 healthy cumulus-oocyte complexes (COCs) per ovary are collected and subjected to IVP procedures (Merton et al., 2003), each ovary produces 1.75 blastocyst that finally gives approximately 0.6 calves born (Fig. 1). On a per animal basis, the IVP system brings a modest improvement respect to the physiological condition of a mono-ovular species and very close to mother's nature results after 29 million years of natural selection and evolution in the bovine lineage.

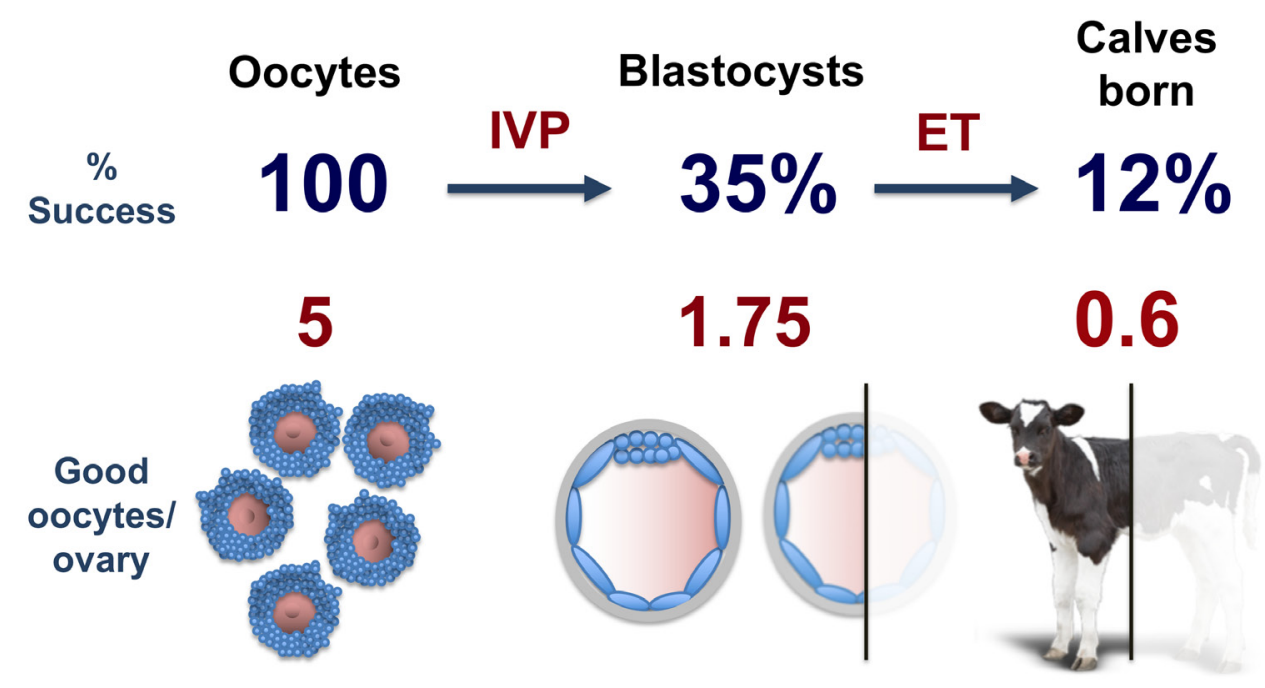

1.2 good oocyte/cow

Figure 1. The current efficiency of standard IVP system in the bovine species. 


\section{The physiological issue}

The quality of the oocytes is pivotal for assisted reproductive technologies outcome and the maturation of the oocyte represents the first key limiting step of the IVP system. Researches are trying to deal with the improvement of IVP systems and in particular with the IVM step.

Development of IVM techniques was made possible starting from 1935' Pincus and Enzmann observation that oocytes removed from antral follicles before natural ovulation spontaneously resume meiosis (Pincus and Enzmann, 1935). Thus, in standard IVM techniques, oocytes are collected from antral follicles and cultured in vitro up to the metaphase II (MII) stage with the emission of the first polar body. However, when oocytes are collected in pools from antral follicles, the processes necessary to confer full meiotic and developmental competence must be completed in a considerably high proportion of them. As a result, the oocytes ability to be fertilized or develop into embryos or to term might be compromised.

In the cyclic cow, the oocyte reaches its final size of around $120 \mu \mathrm{m}$ when the follicle ranges a diameter of 2-3 mm (Fair et al., 1995). The selection for dominance occurs when the follicles develop from 3 to $8 \mathrm{~mm}$ (Dieleman et al., 2002; Adams et al., 2008). Moreover, additional and essential processes occur in vivo during the following follicular growth and dominance phase until ovulation (Blondin et al., 1997), when follicles reach a diameter of about $15 \mathrm{~mm}$ (Lussier et al., 1987; Fortune, 1994). These processes are referred to as prematuration or capacitation and occur when a follicle is selected to become dominant and are accomplished shortly before the LH surge triggers the final maturation, as depicted in Fig. 2 (Hyttel et al., 1997; Mermillod and Marchal, 1999; Dieleman et al., 2002). Therefore, in the IVP practice, only few oocytes collected from 3-8 $\mathrm{mm}$ antral follicles develop in vitro into blastocysts and result in viable offspring after transfer presumably because they did not complete the dominant and preovulatory follicular development, which are crucial for the achievement of the full competence proper of the ovulatory oocyte (Hyttel et al., 1997; Dieleman et al., 2002).

From the above observations, it is clear that even if an oocyte collected from a $3 \mathrm{~mm}$ follicle has an intrinsic capacity to develop into an embryo after IVMIVF-IVC, it still requires an additional time to acquire all of the capabilities leading to successful implantation in the uterus and maintenance of gestation to term and to yield healthy offspring, after IVF and IVC. These studies have naturally led to the design of in vitro approaches that take into account the need for the oocyte to complete its differentiation, namely a prematuration or capacitation step before in vitro maturation.

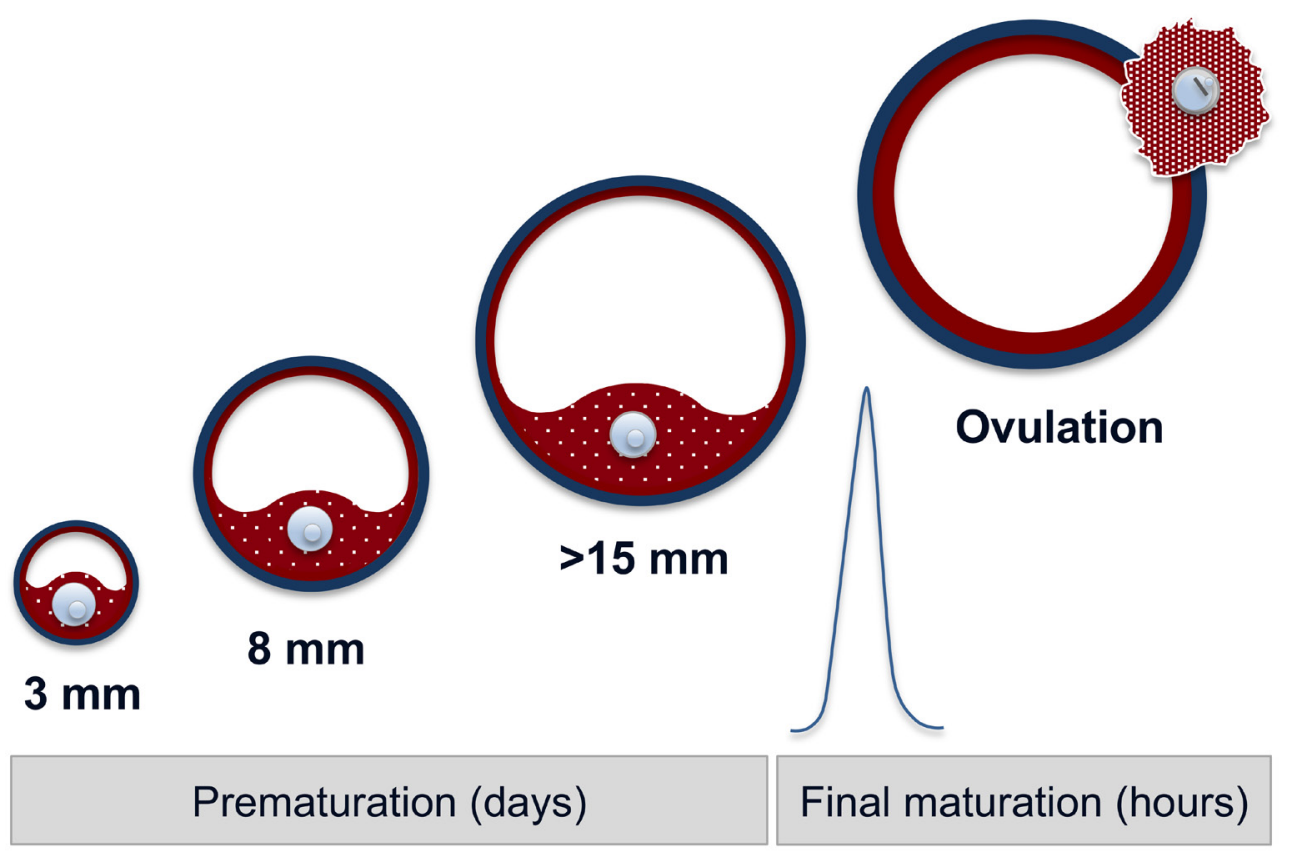

Figure 2. A schematic representation of the prematuration concept. Prematuration refers to the processes occurring in vivo during the phase of selection for dominance, when the follicles develop from 3 to $8 \mathrm{~mm}$, and successively when a follicle is selected to become dominant. Finally, prematuration is accomplished shortly before the LH surge triggers the final maturation.

\section{The in vitro prematuration step}

\section{Controlling cAMP}

The identification of the mechanisms that control oocyte meiotic arrest and resumption (reviewed in Conti et al., 2012) has provided the molecular tools to block or delay spontaneous meiotic resumption after removal from the follicle in in vitro prematuration studies (reviewed in Bilodeau-Goeseels, 2012). A firmly established concept is that meiotic arrest of the oocyte relies on high concentrations of the second messenger cyclic AMP (cAMP; Cho et al., 1974; Dekel and Beers 1978; reviewed in Conti et al., 2012), which 
is known to regulate oocyte and granulosa cell functions (Luciano and Peluso 1995; Conti, 2002). Oocyte cAMP level is sustained by endogenous adenylate cyclase and constitutively active G-protein-coupled receptors (Mehlmann et al., 2002). cAMP is generated also by cumulus cells and then transported into the oocyte through gap junctions (Anderson and Albertini, 1976; Bornslaeger and Schultz, 1985; Luciano et al., 2005). At the same time, intra-oocyte cAMP concentration is regulated by the activity of the oocyte specific phosphodiesterase 3A (PDE3A) enzyme that degrades cAMP into 5'AMP (Tsafriri et al., 1996), whose activity is inhibited by cyclic guanosine 3',5'-monophosphate (cGMP; Norris et al., 2009; Vaccari et al., 2009). cGMP is produced in the cumulus cells upon the activation of the guanilyl-cyclase coupled natriuretic peptide receptor type-2 (NPR2; Robinson et al., 2012) whose activity is induced by its ligand natriuretic peptide precursor $\mathrm{C}$ (CNP), which is mainly synthesized by mural granulosa cells (Zhang et al., 2010, 2011). cGMP is then transferred via gap junctions (Richard and Baltz, 2014) to the oocyte where it inhibits PDE3A thus contributing to the maintenance of meiotic arrest (Norris et al., 2009; Vaccari et al., 2009).

Several physiological methods for artificially maintaining meiotic arrest in bovine oocytes have been developed since 1980' with variable success (Leibfried and First, 1980; Sirard and Bilodeau, 1990; Sirard and Coenen, 1993; De Loos et al., 1994; Richard and Sirard, 1996; Fouladi Nashta et al., 1998). Starting from the modulation of cAMP content, numerous IVM systems have been suggested for stimulating oocyte maturation and embryonic developmental competence acquisition (Gilchrist et al., 2016).

Numerous pharmacological and physiological agents have been used to modulate the oocyte cAMP concentration in order to temporally control the oocyte's meiotic arrest and resumption (Gilchrist et al., 2016). For instance, cAMP concentration has been manipulated through the use of broad-spectrum such as IBMX or specific inhibitors of phosphodiesterases (PDEs) such as cilostamide, milrinone or Org9935, by activators of adenylate cyclase (forskolin, iAC), through cAMP analogs (dbcAMP) or by a combination of these agents. Several laboratories have shown that a delay of meiotic resumption has a beneficial effect on embryonic developmental competence. Specifically, the manipulation of intracellular cAMP concentration affects the functional coupling between oocyte and cumulus cells so that a decrease in cAMP determines a drop in gap junction-mediated intercellular communications (Luciano et al., 2004; Thomas et al., 2004). On the other hand, treatments that sustained the intracellular cAMP level prevented the loss of cumulusoocyte communications and increased oocyte developmental competence (Luciano et al., 1999, 2011; Guixue et al., 2001; Modina et al., 2001; Atef et al., 2005; Nogueira et al., 2006; Ozawa et al., 2008; Shu et al., 2008; Nogueira and Vanhoutte, 2009; Albuz et al., 2010; Dieci et al., 2013; Lodde et al., 2013; Rose et al., 2013; Zeng et al., 2013; Richani et al., 2014). In different systems the preservation of the cAMP concentration during several hours of prematuration culture seems to be the main requirement to promote regular chromatin transition thus endorsing oocyte differentiation (Nogueira et al., 2006; Vanhoutte et al., 2007; Luciano et al., 2011; Dieci et al., 2013; Lodde et al., 2013; Sanchez et al., 2015) and an increase in embryonic developmental competence and/or quality (Luciano et al., 2011; Dieci et al., 2013; Lodde et al., 2013; Franciosi et al., 2014; Azari-Dolatabad et al., 2016; Li et al., 2016; Park et al., 2016; Soares et al., 2017).

However, in most of the above cited cases the reported results showed only a slight improvement in developmental competence depending on the approach used. Often, rather than increasing the number of blastocysts obtained, an improvement in the parameters related to embryo quality was observed (Luciano et al., 2011; Dieci et al., 2013, 2016; Lodde et al., 2013; Rose et al., 2013; Franciosi et al., 2014; Zeng et al., 2014; Azari-Dolatabad et al., 2016; Li et al., 2016; Park et al., 2016; Sanchez et al., 2017; Soares et al., 2017). For instance, blastocysts with higher number of cells or embryo with better developmental kinetics. In other cases, results showed no significant improvement over the current standard in vitro embryo production system (Jee et al., 2009; Gharibi et al., 2013; Guimaraes et al., 2015; Diogenes et al., 2017).

\section{Controlling $M P F$}

In addition to cyclic nucleotide manipulationbased methods, other approaches have been used to prevent meiotic resumption. Downstream to cAMP transduction pathway is M-phase promoting factor (MPF), a heterodimer consisting of a kinase, cdk1 and its regulatory partner, cyclin B (cdk1-cyclin B), which is involved in the regulation of $\mathrm{G} 2 / \mathrm{M}$ cell cycle transition of all eukaryotic cells. Cyclic AMP-mediated Protein Kinase A (PKA) activity inhibits Cdk1 hence contributing to oocyte meiotic arrest (Mehlmann, 2005). The activation of MPF is also a key point of meiotic resumption in oocytes that corresponds to a $G 2 / \mathrm{M}$ transition (Jones, 2004; Mehlmann, 2005).

Several pharmacological approaches aimed to interfere with MPF activity have been used to artificially maintain mammalian oocyte in meiotic arrest. Cell permeable and selective inhibitors of the CDK1/cyclin B kinase, butyrolactone-I (Kitagawa et al., 1993) and roscovitine (Meijer et al., 1997) have received more attention. Butyrolactone-I has been shown to reversibly inhibit meiotic resumption in bovine (Kubelka et al., 2000; Lonergan et al., 2000; Ponderato et al., 2001, 2002; Imai et al., 2002; Adona et al., 2008; Ferreira et al., 2009; De Bem et al., 2011) and pig (Wu et al., 2002) oocytes for $24 \mathrm{~h}$ without negatively affecting the subsequent development to the blastocyst stage. Similarly, roscovitine was effective in reversibly maintain oocyte meiotic arrest in both cow (Mermillod et al., 2000; Sa Barretto et al., 2011) and pig (Marchal et al., 2001). Moreover, the combination of both substances did not cause detrimental effects on development to the blastocyst stage (Ponderato et al., 2001), and subsequent early stages of organogenesis 
(Ponderato et al., 2002). However, when compared to the standard IVP system, the majority of the studies reported no significant improvements in embryonic developmental competence when oocytes were arrested with MPF inhibitors and subsequently matured and fertilized in vitro. Nonetheless, the use of butyrolactone and roscovitine have been reported to induce some modifications in the oocytes at ultrastructural level (Lonergan et al., 2003), and whether or not these modifications are compatible with normal gestation and live births is still debated.

\section{What's the matter with in vitro prematuration?}

Notwithstanding the meiotic arrest method used, little to no improvement has been observed in the embryonic developmental competence when oocytes were cultured in bulk, regardless their follicular origin. We believe that the high heterogeneity of the population of COCs subjected to in vitro prematuration protocols is responsible for its limited success rate. In most of the cases, indeed, studies on in vitro prematuration efficiency have been conducted on ovaries obtained from slaughtered animals, thus contain all types and sizes of antral follicles representing different stages of oocyte development. Considering that in the absence of hormonal synchronization treatments, the follicle population in the ovary is heterogeneous, the stage of differentiation of the oocyte should be taken into account (Luciano and Sirard, 2018). In the following paragraphs we will describe the studies that sustain this hypothesis and, at the same time, have led to define morphological and molecular markers to identify the most suitable prematuration conditions.

\section{A pre-maturation approach thoughtful of oocyte physiology}

The oocyte acquires developmental competence just prior to ovulation. Oocyte developmental competence is usually defined as the ability of a female gamete to mature into an egg with its capability to be fertilized and sustain embryo development to the blastocyst stage (Conti and Franciosi, 2018). Nevertheless, identifying oocytes that have achieved the final competence is extremely arduous. One morphological indicator is large-scale chromatin configuration, which changes while the oocyte grows and differentiates during follicular antral development (De La Fuente, 2006; Luciano and Lodde, 2013). This has led to the identification of distinct stages in which the chromatin becomes progressively more compact and occupies a smaller area of the oocyte nucleus or germinal vesicle $(\mathrm{GV})$ in all mammals studied so far (reviewed in Luciano and Lodde 2013; Luciano et al., 2014).

In cows, the four chromatin configurations described correspond to different stages of developmental competence (Lodde et al., 2007). In the GV0 configuration the chromatin appears mostly uncondensed and dispersed throughout the nucleoplasm, while the appearance of few foci of condensation marks the transition to the GV1 configuration. Further compaction into distinct aggregates characterizes the GV2 configuration while the highest level of compaction occurs in GV3, where the chromatin appears as a single clump in a restricted area of the nucleus (Lodde et al., 2007). These stages accompany follicle development. Nearly $90 \%$ of the oocytes isolated from early antral follicles $(0.5$ to $2 \mathrm{~mm}$ in diameter) show a GV0 configuration, while medium antral follicles $(2-8 \mathrm{~mm})$, which are the follicles most commonly used for IVP, contain nearly no GV0-stage oocytes but GV1, GV2 and GV3 stages in similar proportions (Lodde et al., 2007).

Chromatin configuration is not simply morphology, but a marker of gamete differentiation associated with various functional features (Luciano et al., 2014). In bovine oocytes, the transition from GV0 to GV3 corresponds to progressive transcription silencing (Lodde et al., 2008), changes in epigenetic signatures such as overall methylation (Lodde et al., 2009) and histone modification (Labrecque et al., 2015; Lodde et al., 2017) and changes in nuclear architecture and cytoplasmic organelle redistribution (Lodde et al., 2008). More importantly, the transition from dispersed to compacted chromatin is accompanied by gradual acquisition of meiotic and developmental competence (Lodde et al., 2007, 2008; Luciano et al., 2011). Similar correlations have been described in mice and humans (Zuccotti et al., 1995; Bouniol-Baly et al., 1999; Combelles et al., 2003; Miyara et al., 2003; Sanchez et al., 2015). It is noteworthy that the changes in chromatin configuration also accompany significant changes in the transcriptome signature in the oocyte (Labrecque et al., 2015) and in the corresponding cumulus cells (Dieci et al., 2016) suggesting that chromatin configuration also reflects phases of follicle development (Luciano and Sirard, 2018). Moreover, large-scale changes in chromatin configuration are related to gap-junction functional status through cAMP dependent mechanisms (Luciano et al., 2011; Lodde et al., 2013;Franciosi et al., 2014). In cumulus-oocyte complexes isolated from early antral follicles, characterized by a GV0 chromatin configuration, the maintenance of functional gap-junction communications promotes oocyte growth, gradual transcriptional silencing, large-scale chromatin remodeling and competence acquisition, all of which are controlled via cAMP mediated mechanism (Luciano et al., 2011).

A clear indication that the success of in vitro prematuration using cAMP modulators is affected by oocyte heterogeneity, comes from our recent study in cows showing that prematuration may be beneficial for the developmental competence of GV1 oocytes but detrimental for that of GV3 oocytes (Dieci et al., 2016). Previous studies have shown that oocytes within COCs with compact cumulus and homogeneous ooplasm are less competent than those in which the ooplasm appears granulated and the outer layers of cumulus cells exhibit the slight expansion often seen in early atretic follicles (Blondin and Sirard, 1995). In our study, we have shown that oocytes within COCs with compact cumulus and homogeneous ooplasm, tend to be in the GV1 chromatin configuration (loosely condensed). On the contrary in COCs with slight expansion and/or 
granulated cytoplasm the oocyte chromatin is in either the GV2 or the GV3 configuration, while GV1 representation is negligible (Fig. $3 \mathrm{~A}, \mathrm{~B}$; Dieci et al., 2016). In our experiments the GV1-enriched oocyte population benefited of a $6 \mathrm{~h}$ of prematuration treatment with cilostamide and physiological concentration of
FSH, whereas standard IVM without pretreatment leads to poor pre-implantation development. Strikingly, the same prematuration protocol decreases the blastocyst rate of GV2-GV3 enriched oocyte population (Dieci et al., 2016), which performed better if directly processed for IVM (Fig. 3 D).

A

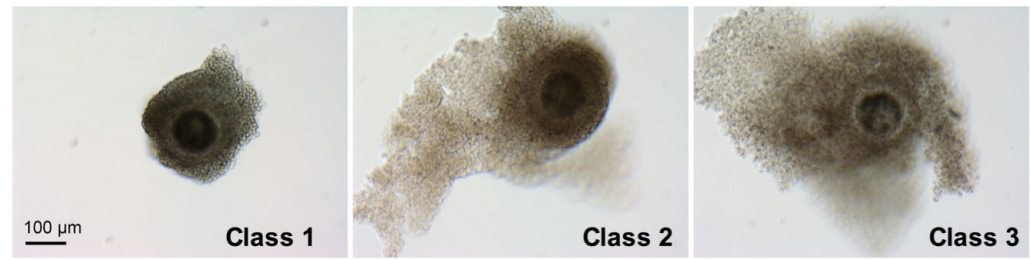

B
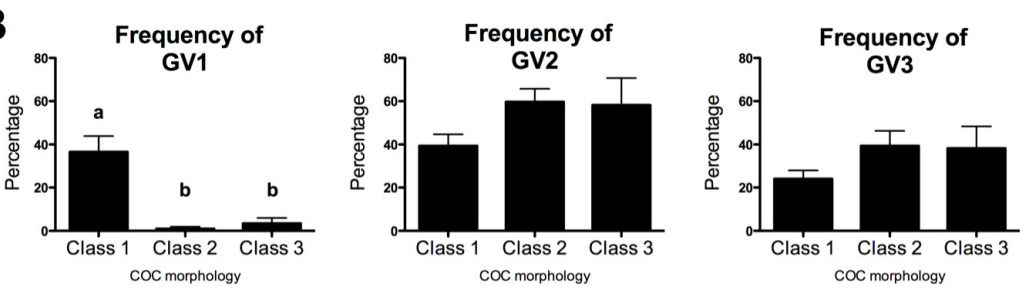

C
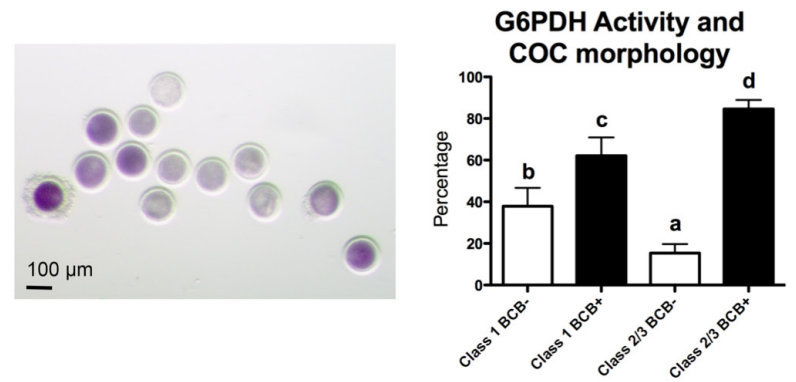

D
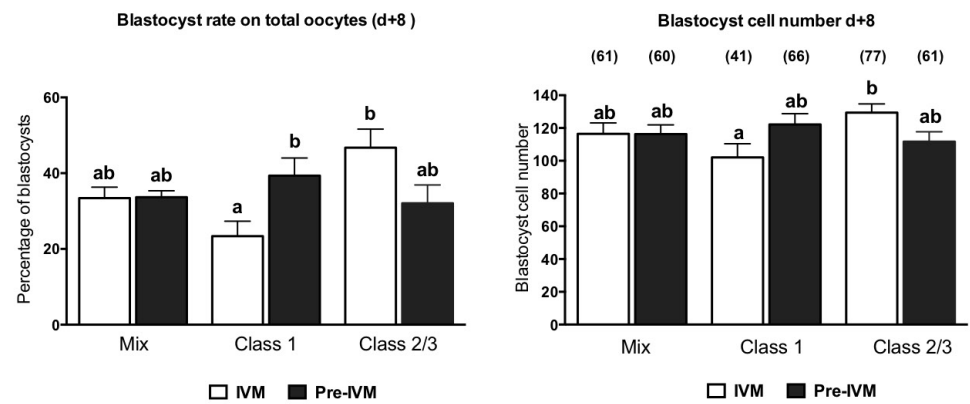

Figure 3. A. Representative images of class 1, class 2 and class 3 COCs. (Class 1: homogeneous ooplasm and absence of expansion of outer layer CC; Class 2: minor granulation of the ooplasm and/or beginning of expansion of outer layer CC; Class 3: highly granulated ooplasm and few CC layers showing expansion). B. Graphs show the frequency of GV1, GV2 and GV3 chromatin configurations in each class. C. After collection, COC were separated into Class 1 and Class $2 / 3$ on the basis of their morphology and subjected to Brilliant Cresyl Blue staining (BCB). After removal of $\mathrm{CC}$, oocytes were classified as $\mathrm{BCB}+$ or $\mathrm{BCB}-$ as shown in the representative picture. Graph shows the percentage of $\mathrm{BCB}+$ and $\mathrm{BCB}$ - oocytes in Class 1 and 2/3 COC. A total of $337 \mathrm{COC}$ were analyzed (126 Class 1 and 211 of Class 2/3) in nine independent experiments. D. Effect of pre-maturation treatment on COC with different morphology. After collection, COC were separated into Class 1 and Class $2 / 3$ on the basis of their morphology and in vitro matured with or without the pre-IVM treatment. Then, oocytes were in-vitro fertilized and in-vitro cultured for 8 days. Groups of unsorted COC (mix of Class 1/2/3) were subjected to the same experimental procedure and were used as controls. Graphs show the effect of the pre-IVM treatment on the blastocyst rate (left) and mean cell number per blastocyst (right). A total of 947 oocytes were analyzed in this study (292 mixed oocytes, 321 Class 1 and 334 Class 2/3) in six independent experiments.

Data were analyzed by one-way ANOVA followed by Newman-Keuls multiple comparison test; data are expressed as means \pm SEM; a, b: different letters indicates significant differences $(\mathrm{P}<0.05)$. From Dieci et al., 2016. 
Noteworthy, in animal models characterized by a more homogeneous population of oocytes, prematuration protocols substantially improved the developmental competence. Significant effects were obtained in oocytes with an inherent low embryonic developmental competence such as prepubertal calves, with the use of butyrolactone-I and roscovitine (Donnay et al., 2004) and juvenile mice, with the use of CNP and low concentration of FSH (Romero et al., 2016). Oocytes isolated from early antral follicles (mostly GV0), growth in the presence of cilostamide and a physiologic concentration of FSH were successfully brought to meiotic and embryonic developmental competence (Luciano et al., 2011). In the same line, human oocytes derived from small antral follicles, which have an intrinsically low developmental potential (Sanchez et al., 2017), or compact COCs that are less meiotically competent and characterized by uncondensed chromatin (Nogueira et al., 2006; Sanchez et al., 2017), progressed to a condensed chromatin configuration when prematuration was applied (Vanhoutte et al., 2007).

Moreover, when COCs were selected as homogeneous populations of growing and fully grown oocytes by brilliant cresyl blue staining (Fig. 2 C), the population of growing oocytes was greatly enhanced in embryonic developmental capability while the effect of prematuration was detrimental on the population of fully grown oocytes (Azari-Dolatabad et al., 2016; Dieci et al., 2016; Wang et al., 2016).

\section{Conclusions}

The goal of IVP technologies is to improve oocyte quality through a physiological approach in order to obtain a higher number of oocytes with elevated developmental competence. Oocytes coming from non-ovulatory follicles, although can spontaneously resume meiosis are still far to be fully competent. Regardless of the meiotic arrest method used, the rationale of most of the studies aimed at reproducing in vitro the final stages of prematuration that normally occur in vivo. Several studies have served as proof of concept that prematuration can improve the developmental competence of the oocyte. Nevertheless, little advance has been observed in the embryonic developmental competence when oocytes were cultured in bulk regardless their follicular origin.

The heterogeneity of oocyte population at the start of the procedure greatly affects the outcome of prematuration systems and the specific metabolic needs of the oocyte at the time of isolation should be taken into account. The identification of specific non-invasive biomarker(s) of oocyte health status and final differentiation can provide useful tools for the selection of good quality oocyte, time of prematuration (culture length) as well as the specific environment (hormones, growth factors, molecules, etc.) for optimizing prematuration culture systems. At the same time, the definition of customized culture system can be associated with stimulation strategies to synchronize the growth of ovarian follicles in the donor in order to obtain oocytes specifically suitable for tailored prematuration protocols.

\section{Competing interest}

The authors declare that there is no conflict of interest that could be perceived as prejudicing the impartiality their presentation of the research findings mentioned in this work.

\section{References}

Adams GP, Jaiswal R, Singh J, Malhi P. 2008. Progress in understanding ovarian follicular dynamics in cattle. Theriogenology, 69:72-80.

Adona PR, Pires PR, Quetglas MD, Schwarz KR, Leal CL. 2008. Prematuration of bovine oocytes with butyrolactone. I: effects on meiosis progression, cytoskeleton, organelle distribution and embryo development. Anim Reprod Sci, 108:49-65.

Albuz FK, Sasseville M, Lane M, Armstrong DT, Thompson JG, Gilchrist RB. 2010. Simulated physiological oocyte maturation (SPOM): a novel in vitro maturation system that substantially improves embryo yield and pregnancy outcomes. Hum Reprod, 25:2999-3011.

Anderson E, Albertini DF. 1976. Gap junctions between the oocyte and companion follicle cells in the mammalian ovary. J Cell Biol, 71:680-686.

Atef A, Paradis F, Vigneault C, Sirard MA. 2005. The potential role of gap junction communication between cumulus cells and bovine oocytes during in vitro maturation. Mol Reprod Dev, 71:358-367.

Azari-Dolatabad N, Rahmani HR, Hajian M, Ostadhosseini S, Hosseini SM, Nasr-Esfahani MH. 2016. Effects of cilostamide and/or forskolin on the meiotic resumption and development competence of growing ovine oocytes selected by brilliant cresyl blue staining. Theriogenology, 85:1483-1490.

Bilodeau-Goeseels S. 2012. Bovine oocyte meiotic inhibition before in vitro maturation and its value to in vitro embryo production: does it improve developmental competence? Reprod Domest Anim, 47:687-693.

Blondin P, Sirard MA. 1995. Oocyte and follicular morphology as determining characteristics for developmental competence in bovine oocytes. Mol Reprod Dev, 41:54-62.

Blondin P, Coenen K, Guilbault LA, Sirard MA. 1997. In vitro production of bovine embryos: developmental competence is acquired before maturation. Theriogenology, 47:1061-1075.

Bornslaeger EA, Schultz RM. 1985. Regulation of mouse oocyte maturation: effect of elevating cumulus cell cAMP on oocyte cAMP levels. Biol Reprod, 33:698-704.

Bouniol-Baly C, Hamraoui L, Guibert J, Beaujean N, Szollosi MS, Debey P. 1999. Differential transcriptional activity associated with chromatin configuration in fully grown mouse germinal vesicle oocytes. Biol Reprod, 60:580-587.

Cho WK, Stern S, Biggers JD. 1974. Inhibitory effect 
of dibutyryl cAMP on mouse oocyte maturation in vitro. $J$ Exp Zool, 187:383-386.

Combelles CM, Albertini DF, Racowsky C. 2003. Distinct microtubule and chromatin characteristics of human oocytes after failed in-vivo and in-vitro meiotic maturation. Hum Reprod, 18:2124-2130.

Conti M. 2002. Specificity of the cyclic adenosine 3',5'monophosphate signal in granulosa cell function. Biol Reprod, 67:1653-1661.

Conti M, Hsieh M, Zamah AM, Oh JS. 2012. Novel signaling mechanisms in the ovary during oocyte maturation and ovulation. Mol Cell Endocrinol, 356:6573.

Conti M, Franciosi F. 2018. Acquisition of oocyte competence to develop as an embryo: integrated nuclear and cytoplasmic events. Hum Reprod Update, 24:245266.

De Bem TH, Chiaratti MR, Rochetti R, Bressan FF, Sangalli JR, Miranda MS, Pires PR, Schwartz KR, Sampaio RV, Fantinato-Neto P, Pimentel JR, Perecin F, Smith LC, Meirelles FV, Adona PR, Leal CL. 2011. Viable calves produced by somatic cell nuclear transfer using meiotic-blocked oocytes. Cell Reprogram, 13:419-429.

De La Fuente R. 2006. Chromatin modifications in the germinal vesicle $(\mathrm{GV})$ of mammalian oocytes. Dev Biol, 292:1-12.

De Loos FA, Zeinstra E, Bevers MM. 1994. Follicular wall maintains meiotic arrest in bovine oocytes cultured in vitro. Mol Reprod Dev, 39:162-165.

Dekel N, Beers WH. 1978. Rat oocyte maturation in vitro: relief of cyclic AMP inhibition by gonadotropins. Proc Natl Acad Sci USA, 75:4369-4373.

Dieci C, Lodde V, Franciosi F, Lagutina I, Tessaro I, Modina SC, Albertini DF, Lazzari G, Galli C, Luciano AM. 2013. The effect of cilostamide on gap junction communication dynamics, chromatin remodeling, and competence acquisition in pig oocytes following parthenogenetic activation and nuclear transfer. Biol Reprod, 89:68. doi: 10.1095/biolreprod.113.110577.

Dieci C, Lodde V, Labreque R, Dufort I, Tessaro I, Sirard MA, Luciano AM. 2016. Differences in cumulus cell gene expression indicate the benefit of a pre-maturation step to improve in-vitro bovine embryo production. Mol Hum Reprod, 22:882-897.

Dieleman SJ, Hendriksen PJ, Viuff D, Thomsen PD, Hyttel P, Knijn HM, Wrenzycki C, Kruip TA, Niemann H, Gadella BM, Bevers MM, Vos PL. 2002. Effects of in vivo prematuration and in vivo final maturation on developmental capacity and quality of pre-implantation embryos. Theriogenology, 57:5-20.

Diogenes MN, Guimaraes ALS, Leme LO, Mauricio MF, Dode MAN. 2017. Effect of prematuration and maturation with fibroblast growth factor 10 (FGF10) on in vitro development of bovine oocytes. Theriogenology, 102:190-198.

Donnay I, Faerge I, Grondahl C, Verhaeghe B, Sayoud H, Ponderato N, Galli C, Lazzari G. 2004. Effect of prematuration, meiosis activating sterol and enriched maturation medium on the nuclear maturation and competence to development of calf oocytes.
Theriogenology, 62:1093-1107.

Fair T, Hyttel P, Greve T. 1995. Bovine oocyte diameter in relation to maturational competence and transcriptional activity. Mol Reprod Dev, 42:437-442.

Ferreira EM, Vireque AA, Adona PR, Ferriani RA, Navarro PA. 2009. Prematuration of bovine oocytes with butyrolactone I reversibly arrests meiosis without increasing meiotic abnormalities after in vitro maturation. Eur J Obstet Gynecol Reprod Biol, 145:7680

Fortune JE. 1994. Ovarian follicular growth and development in mammals. Biol Reprod, 50:225-232.

Fouladi Nashta AA, Waddington D, Campbell KH. 1998. Maintenance of bovine oocytes in meiotic arrest and subsequent development In vitro: A comparative evaluation of antral follicle culture with other methods. Biol Reprod, 59:255-262.

Franciosi F, Coticchio G, Lodde V, Tessaro I, Modina SC, Fadini R, Dal Canto M, Renzini MM, Albertini DF, Luciano AM. 2014. Natriuretic peptide precursor $\mathrm{C}$ delays meiotic resumption and sustains gap junction-mediated communication in bovine cumulusenclosed oocytes. Biol Reprod, 91:61. doi: 10.1095/biolreprod.114.118869.

Galli C. 2017. Achievements and unmet promises of assisted reproduction technologies in large animals: a per-sonal perspective. Anim Reprod, 14:614-621.

Gharibi S, Hajian M, Ostadhosseini S, Hosseini SM, Forouzanfar M, Nasr-Esfahani MH. 2013. Effect of phosphodiesterase type 3 inhibitor on nuclear maturation and in vitro development of ovine oocytes. Theriogenology, 80:302-312.

Gilchrist RB, Luciano AM, Richani D, Zeng HT, Wang X, Vos MD, Sugimura S, Smitz J, Richard FJ, Thompson JG. 2016. Oocyte maturation and quality: role of cyclic nucleotides. Reproduction, 152:R143-157. Guimaraes AL, Pereira SA, Leme LO, Dode MA. 2015. Evaluation of the simulated physiological oocyte maturation system for improving bovine in vitro embryo production. Theriogenology, 83:52-57.

Guixue Z, Luciano AM, Coenen K, Gandolfi F, Sirard MA. 2001. The influence of cAMP before or during bovine oocyte maturation on embryonic developmental competence. Theriogenology, 55:17331743.

Hyttel P, Fair T, Callesen H, Greve T. 1997. Oocyte growth, capacitation and final maturation in cattle. Theriogenology, 47:23-32.

Imai K, Kobayashi S, Kaneyama K, Kojima T, Nagai T. 2002. Effects of butyrolactone-I on GVBD in bovine oocytes and subsequent maturation, fertilization and development in vitro. $J$ Reprod Dev, 48:249-255.

Jee BC, Chen HY, Chian RC. 2009. Effect of a phosphodiesterase type 3 inhibitor in oocyte maturation medium on subsequent mouse embryo development. Fertil Steril, 91(5 suppl):2037-2042.

Jones KT. 2004. Turning it on and off: M-phase promoting factor during meiotic maturation and fertilization. Mol Hum Reprod, 10:1-5.

Kitagawa M, Okabe T, Ogino $H$, Matsumoto $H$, Suzuki-Takahashi I, Kokubo T, Higashi H, Saitoh S, Taya Y, Yasuda H, et al. 1993. Butyrolactone I, a 
selective inhibitor of cdk2 and cdc2 kinase. Oncogene, 8:2425-2432.

Kubelka M, Motlik J, Schultz RM, Pavlok A. 2000. Butyrolactone I reversibly inhibits meiotic maturation of bovine oocytes, without influencing chromosome condensation activity. Biol Reprod, 62:292-302.

Labrecque R, Lodde V, Dieci C, Tessaro I, Luciano AM, Sirard MA. 2015. Chromatin remodelling and histone mRNA accumulation in bovine germinal vesicle oocytes. Mol Reprod Dev, 82:450-462.

Leibfried L, First NL. 1980. Effect of bovine and porcine follicular fluid and granulosa cells on maturation of oocytes in vitro. Biol Reprod, 23:699-704. Li HJ, Sutton-McDowall ML, Wang X, Sugimura S, Thompson JG, Gilchrist RB. 2016. Extending prematuration with cAMP modulators enhances the cumulus contribution to oocyte antioxidant defence and oocyte quality via gap junctions. Hum Reprod, 31:810821.

Lodde V, Modina S, Galbusera C, Franciosi F, Luciano AM. 2007. Large-scale chromatin remodeling in germinal vesicle bovine oocytes: interplay with gap junction functionality and developmental competence. Mol Reprod Dev, 74:740-749.

Lodde V, Modina S, Maddox-Hyttel P, Franciosi F, Lauria A, Luciano AM. 2008. Oocyte morphology and transcriptional silencing in relation to chromatin remodeling during the final phases of bovine oocyte growth. Mol Reprod Dev, 75:915-924.

Lodde V, Modina SC, Franciosi F, Zuccari E, Tessaro I, Luciano AM. 2009. Localization of DNA methyltransferase-1 during oocyte differentiation, in vitro maturation and early embryonic development in cow. Eur J Histochem, 53:199-207.

Lodde V, Franciosi F, Tessaro I, Modina SC, Luciano AM. 2013. Role of gap junction-mediated communications in regulating large-scale chromatin configuration remodeling and embryonic developmental competence acquisition in fully grown bovine oocyte. $J$ Assist Reprod Genet, 30:1219-1226.

Lodde V, Luciano AM, Franciosi F, Labrecque R, Sirard MA. 2017. Accumulation of chromatin remodelling enzyme and histone transcripts in bovine oocytes. Results Probl Cell Differ, 63:223-255.

Lonergan P, Dinnyes A, Fair T, Yang X, Boland M. 2000. Bovine oocyte and embryo development following meiotic inhibition with butyrolactone I. Mol Reprod Dev, 57:204-209.

Lonergan P, Faerge I, Hyttel PM, Boland M, Fair T. 2003. Ultrastructural modifications in bovine oocytes maintained in meiotic arrest in vitro using roscovitine or butyrolactone. Mol Reprod Dev, 64:369-378.

Lonergan P, Fair T. 2008. In vitro-produced bovine embryos: dealing with the warts. Theriogenology, 69:17-22.

Luciano AM, Peluso JJ. 1995. Effect of in vivo gonadotropin treatment on the ability of progesterone, estrogen, and cyclic adenosine 5'-monophosphate to inhibit insulin-dependent granulosa cell mitosis in vitro. Biol Reprod, 53:664-669.

Luciano AM, Pocar P, Milanesi E, Modina S, Rieger D, Lauria A, Gandolfi F. 1999. Effect of different levels of intracellular cAMP on the in vitro maturation of cattle oocytes and their subsequent development following in vitro fertilization. Mol Reprod Dev, 54:8691.

Luciano AM, Modina S, Vassena R, Milanesi E, Lauria A, Gandolfi F. 2004. Role of intracellular cyclic adenosine 3',5'-monophosphate concentration and oocyte-cumulus cells communications on the acquisition of the developmental competence during in vitro maturation of bovine oocyte. Biol Reprod, 70:465472.

Luciano AM, Lodde V, Beretta MS, Colleoni S, Lauria A, Modina S. 2005. Developmental capability of denuded bovine oocyte in a co-culture system with intact cumulus-oocyte complexes: role of cumulus cells, cyclic adenosine 3',5'-monophosphate, and glutathione. Mol Reprod Dev, 71:389-397.

Luciano AM, Franciosi F, Modina SC, Lodde V. 2011. Gap junction-mediated communications regulate chromatin remodeling during bovine oocyte growth and differentiation through cAMP-dependent mechanism(s). Biol Reprod, 85:1252-1259.

Luciano AM, Lodde V. 2013. Changes of large-scale chromatin configuration during mammalian oocyte differentiation. In: Coticchio G, Albertini DF, De Santis L (Ed.). Oogenesis. London: Springer. pp. 93-108.

Luciano AM, Franciosi F, Dieci C, Lodde V. 2014. Changes in large-scale chromatin structure and function during oogenesis: a journey in company with follicular cells. Anim Reprod Sci, 149:3-10.

Luciano AM, Sirard MA. 2018. Successful in vitro maturation of oocytes: a matter of follicular differentiation. Biol Reprod, 98:162-169.

Lussier JG, Matton P, Dufour JJ. 1987. Growth rates of follicles in the ovary of the cow. J Reprod Fertil, 81:301-307.

Marchal R, Tomanek M, Terqui M, Mermillod P. 2001. Effects of cell cycle dependent kinases inhibitor on nuclear and cytoplasmic maturation of porcine oocytes. Mol Reprod Dev, 60:65-73.

Mehlmann LM, Jones TL, Jaffe LA. 2002. Meiotic arrest in the mouse follicle maintained by a Gs protein in the oocyte. Science, 297(5585):1343-1345.

MehImann LM. 2005. Stops and starts in mammalian oocytes: recent advances in understanding the regulation of meiotic arrest and oocyte maturation. Reproduction, 130:791-799.

Meijer L, Borgne A, Mulner O, Chong JP, Blow JJ, Inagaki N, Inagaki M, Delcros JG, Moulinoux JP. 1997. Biochemical and cellular effects of roscovitine, a potent and selective inhibitor of the cyclin-dependent kinases cdc2, cdk2 and cdk5. Eur J Biochem, 243:527536.

Mermillod P, Marchal R. 1999. [Oocyte of domestic mammals: a model for the study of in vitro maturation]. Contracept Fertil Sex, 27:440-448.

Mermillod P, Tomanek M, Marchal R, Meijer L. 2000. High developmental competence of cattle oocytes maintained at the germinal vesicle stage for 24 hours in culture by specific inhibition of MPF kinase activity. Mol Reprod Dev, 55:89-95.

Merton JS, de Roos AP, Mullaart E, de Ruigh L, 
Kaal L, Vos PL, Dieleman SJ. 2003. Factors affecting oocyte quality and quantity in commercial application of embryo technologies in the cattle breeding industry. Theriogenology, 59:651-674.

Miyara F, Migne C, Dumont-Hassan M, Le Meur A, Cohen-Bacrie P, Aubriot FX, Glissant A, Nathan C, Douard S, Stanovici A, Debey P. 2003. Chromatin configuration and transcriptional control in human and mouse oocytes. Mol Reprod Dev 64:458-470.

Modina S, Luciano AM, Vassena R, Baraldi-Scesi L, Lauria A, Gandolfi F. 2001. Oocyte developmental competence after in vitro maturation depends on the persistence of cumulus-oocyte comunications which are linked to the intracellular concentration of cAMP. Ital $J$ Anat Embryol, 106(2 suppl. 2):241-248.

Nogueira D, Ron-El R, Friedler S, Schachter M, Raziel A, Cortvrindt R, Smitz J. 2006. Meiotic arrest in vitro by phosphodiesterase 3-inhibitor enhances maturation capacity of human oocytes and allows subsequent embryonic development. Biol Reprod, 74:177-184.

Nogueira D, Vanhoutte L. 2009. Use of phosphodiesterase type 3 inhibitor to improve IVM outcome: experimental set up matters. Fertil Steril, 91(5):e3; author reply e4-5. doi.org/10.1016/j.fertnstert. 2008.12.110.

Norris RP, Ratzan WJ, Freudzon M, Mehlmann LM, Krall J, Movsesian MA, Wang $\mathrm{H}$, Ke $\mathrm{H}$, Nikolaev VO, Jaffe LA. 2009. Cyclic GMP from the surrounding somatic cells regulates cyclic AMP and meiosis in the mouse oocyte. Development, 136:18691878 .

Ozawa M, Nagai T, Somfai T, Nakai M, Maedomari N, Fahrudin M, Karja NW, Kaneko H, Noguchi J, Ohnuma K, Yoshimi N, Miyazaki H, Kikuchi K. 2008. Comparison between effects of 3-isobutyl-1methylxanthine and FSH on gap junctional communication, LH-receptor expression, and meiotic maturation of cumulus-oocyte complexes in pigs. Mol Reprod Dev, 75:857-866.

Park B, Lee H, Lee Y, Elahi F, Lee J, Lee ST, Park CK, Hyun SH, Lee E. 2016. Cilostamide and forskolin treatment during pre-IVM improves preimplantation development of cloned embryos by influencing meiotic progression and gap junction communication in pigs. Theriogenology, 86:757-765.

Pincus G, Enzmann EV. 1935. The comparative behavior of mammalian eggs in vivo and in vitro. I. The activation of ovarian eggs. $J$ Exp Med, 62:665-675.

Ponderato N, Lagutina I, Crotti G, Turini P, Galli C, Lazzari G. 2001. Bovine oocytes treated prior to in vitro maturation with a combination of butyrolactone I and roscovitine at low doses maintain a normal developmental capacity. Mol Reprod Dev, 60:579-585.

Ponderato N, Crotti G, Turini P, Duchi R, Galli C, Lazzari G. 2002. Embryonic and foetal development of bovine oocytes treated with a combination of butyrolactone I and roscovitine in an enriched medium prior to IVM and IVF. Mol Reprod Dev, 62:513-518.

Richani D, Wang X, Zeng HT, Smitz J, Thompson JG, Gilchrist RB. 2014. Pre-maturation with cAMP modulators in conjunction with EGF-like peptides during in vitro maturation enhances mouse oocyte developmental competence. Mol Reprod Dev, 81:422435.

Richard FJ, Sirard MA. 1996. Effects of follicular cells on oocyte maturation. II: Theca cell inhibition of bovine oocyte maturation in vitro. Biol Reprod, 54:22-28.

Richard S, Baltz JM. 2014. Prophase I arrest of mouse oocytes mediated by natriuretic peptide precursor $\mathrm{C}$ requires GJA1 (connexin-43) and GJA4 (connexin-37) gap junctions in the antral follicle and cumulus-oocyte complex. Biol Reprod, 90:137. doi: 10.1095/biolreprod. 114.118505.

Robinson JW, Zhang M, Shuhaibar LC, Norris RP, Geerts A, Wunder F, Eppig JJ, Potter LR, Jaffe LA. 2012. Luteinizing hormone reduces the activity of the NPR2 guanylyl cyclase in mouse ovarian follicles, contributing to the cyclic GMP decrease that promotes resumption of meiosis in oocytes. Dev Biol, 366:308316.

Romero S, Sanchez F, Lolicato F, Van Ranst H, Smitz J. 2016. Immature oocytes from unprimed juvenile mice become a valuable source for embryo production when using C-type natriuretic peptide as essential component of culture medium. Biol Reprod, 95:64. doi: 10.1095/biolreprod.116.139808.

Rose RD, Gilchrist RB, Kelly JM, Thompson JG, Sutton-McDowall ML. 2013. Regulation of sheep oocyte maturation using cAMP modulators. Theriogenology, 79:142-148.

Sa Barretto LS, Castro VS, Garcia JM, Mingoti GZ. 2011. Meiotic inhibition of bovine oocytes in medium supplemented with a serum replacer and hormones: effects on meiosis progression and developmental capacity. Zygote, 19:107-116.

Sanchez F, Romero S, De Vos M, Verheyen G, Smitz J. 2015. Human cumulus-enclosed germinal vesicle oocytes from early antral follicles reveal heterogeneous cellular and molecular features associated with in vitro maturation capacity. Hum Reprod, 30:1396-1409.

Sanchez F, Lolicato F, Romero S, De Vos M, Van Ranst H, Verheyen G, Anckaert E, Smitz JEJ. 2017. An improved IVM method for cumulus-oocyte complexes from small follicles in polycystic ovary syndrome patients enhances oocyte competence and embryo yield. Hum Reprod, 32:2056-2068.

Shu YM, Zeng HT, Ren Z, Zhuang GL, Liang XY, Shen HW, Yao SZ, Ke PQ, Wang NN. 2008. Effects of cilostamide and forskolin on the meiotic resumption and embryonic development of immature human oocytes. Hum Reprod, 23:504-513.

Sirard MA, Bilodeau S. 1990. Granulosa cells inhibit the resumption of meiosis in bovine oocytes in vitro. Biol Reprod, 43:777-783.

Sirard MA, Coenen K. 1993. The co-culture of cumulus-enclosed bovine oocytes and hemi-sections of follicles: Effects on meiotic resumption. Theriogenology, 40:933-942.

Soares ACS, Lodde V, Barros RG, Price CA, Luciano AM, Buratini J. 2017. Steroid hormones interact with natriuretic peptide $\mathrm{C}$ to delay nuclear maturation, to maintain oocyte-cumulus communication and to improve the quality of in vitro-produced embryos 
in cattle. Reprod Fertil Dev, 29:2217-2224.

Thomas RE, Thompson JG, Armstrong DT, Gilchrist RB. 2004. Effect of specific phosphodiesterase isoenzyme inhibitors during in vitro maturation of bovine oocytes on meiotic and developmental capacity. Biol Reprod, 71:1142-1149.

Tsafriri A, Chun SY, Zhang R, Hsueh AJ, Conti M. 1996. Oocyte maturation involves compartmentalization and opposing changes of cAMP levels in follicular somatic and germ cells: studies using selective phosphodiesterase inhibitors. Dev Biol, 178:393-402.

Vaccari S, Weeks JL, 2nd, Hsieh M, Menniti FS, Conti M. 2009. Cyclic GMP signaling is involved in the luteinizing hormone-dependent meiotic maturation of mouse oocytes. Biol Reprod, 81:595-604.

Vanhoutte L, De Sutter P, Nogueira D, Gerris $J$, Dhont M, Van der Elst J. 2007. Nuclear and cytoplasmic maturation of in vitro matured human oocytes after temporary nuclear arrest by phosphodiesterase 3-inhibitor. Hum Reprod, 22:12391246.

Wang L, Jiang X, Wu Y, Lin J, Zhang L, Yang N, Huang J. 2016. Effect of milrinone on the developmental competence of growing lamb oocytes identified with brilliant cresyl blue. Theriogenology, 86:2020-2027.

Wu GM, Sun QY, Mao J, Lai L, McCauley TC, Park KW, Prather RS, Didion BA, Day BN. 2002. High developmental competence of pig oocytes after meiotic inhibition with a specific M-phase promoting factor kinase inhibitor, butyrolactone I. Biol Reprod, 67:170177.

Zeng HT, Ren Z, Guzman L, Wang X, SuttonMcDowall ML, Ritter LJ, De Vos M, Smitz J, Thompson JG, Gilchrist RB. 2013. Heparin and cAMP modulators interact during pre-in vitro maturation to affect mouse and human oocyte meiosis and developmental competence. Hum Reprod, 28:15361545.

Zeng HT, Richani D, Sutton-McDowall ML, Ren Z, Smitz JE, Stokes Y, Gilchrist RB, Thompson JG. 2014. Prematuration with cyclic adenosine monophosphate modulators alters cumulus cell and oocyte metabolism and enhances developmental competence of in vitro-matured mouse oocytes. Biol Reprod, 91:47. doi: 10.1095/biolreprod.114.118471.

Zhang M, Su YQ, Sugiura K, Xia G, Eppig JJ. 2010. Granulosa cell ligand NPPC and its receptor NPR2 maintain meiotic arrest in mouse oocytes. Science, 330(6002):366-369.

Zhang M, Su YQ, Sugiura K, Wigglesworth K, Xia G, Eppig JJ. 2011. Estradiol promotes and maintains cumulus cell expression of natriuretic peptide receptor 2 (NPR2) and meiotic arrest in mouse oocytes in vitro. Endocrinology, 152:4377-4385.

Zuccotti M, Piccinelli A, Giorgi Rossi P, Garagna S, Redi CA. 1995. Chromatin organization during mouse oocyte growth. Mol Reprod Dev, 41:479-485. 